\title{
Problems and Countermeasures of teachers' management in local colleges and Universities
}

\author{
Genlian Zhang ${ }^{1, \text { a }}$ \\ ${ }^{1}$ Jilin business and technology college , Jilin, China \\ a24683708@qq.com
}

\begin{abstract}
The level of teacher management is closely related to the quality of education in local colleges and Universities. The existing problems in the management of teachers in local colleges and universities have lowered the quality of higher education and restricted the development of colleges and universities. Restricting the development of colleges and universities include: a single channel of talent introduction; weak teachers; less investment in personnel training; lack of stamina for teachers' development; rigid management; teachers' subjective initiative is not strong. We can improve the management level of teachers from three aspects: to broaden the channels for the introduction of talents, to create teachers training institutions, to strengthen the infiltration of teacher culture, and to highlight the humane management.
\end{abstract}

Keyword: Teacher management; local colleges; Universities

In recent years, the rapid expansion of the scale of colleges and universities, then the number of colleges and universities showed a spurt of growth. Among them, the local universities occupy a large proportion of the higher education is becoming the main body of higher education. China's higher education is big and not strong, and the quality of higher education is not high, improving the quality of education in local colleges and universities will have a significant impact on the overall level of national higher education development. The management of teachers in local universities belongs to the senior human resources management system, strengthen the management of teachers quality is conducive to improve the quality of higher education overall level, determines the quality of personnel training in Colleges and universities and its development level. It is especially important to strengthen the management of university teachers and improve the efficiency of management. At present, there are some problems in the management, we should fully understand and put forward corresponding countermeasures. It is of great significance to improve the management of teachers and improve the quality of higher education.

\section{The existing problems of teacher management in local colleges and Universities}

\subsection{Single channel of talent introduction}

The introduction of talent channels, mainly in two aspects: one is the common source of teachers to inbreeding coefficient, school graduates; two is the introduction of talent is confined to the domestic industry in the talent market. At present, "inbreeding" is still widespread, especially in some local colleges and universities into the main way, which restricts the improvement of the level of teachers in Colleges and universities[1]. At present, China's colleges and universities, especially the key institutions of talent introduction have a global vision. In the face of the global allocation of teacher resources, it is the talent strategy of the first class universities in the global situation[2]. The flow of talent in China is mostly confined to the industry. 


\subsection{Lack of personnel training}

Teachers need teachers to develop their subjective initiative and realize their own development On the one hand. Colleges and universities need to build a good platform for development On the other hand. Local colleges and universities in the higher education system can enjoy less policy. The status of local colleges and universities is lower than that of subordinates. The training and development of the local university teachers are not as good as the subordinate schools. Teacher training in local colleges and universities is characterized by the lack of specialized teacher training institutions. Most university teacher training is responsible for the school personnel department. The Ministry of personnel is mainly responsible for the management of teachers' academic degree, the training of the professional title evaluation and so on, and the development of school-based training.

1.3 Rigid management and weakness of teachers' subjective initiative

The school is just an extension of the administrative system in the educational system in a highly centralized educational system.The school is in full compliance with the rules of the organization. The performance is: the number of administrative staff too much, they play a leading role in the school operation, occupies the core position; teaching and research personnel administrative system is compared with the "screw", participate in the system innovation of rare opportunity, which largely impact school teacher's subjectivity status. When a teacher becomes a "manager" from a running scholar, the teacher's responsibility in teaching, scientific research and social services will be reduced. The institutionalization of local universities is also very strong From the point of view of teaching management. The teaching management in local colleges and universities is mostly empirical, lacking the guidance of scientific theory or only focusing on the organic combination of the theory and method of teaching management in key universities and the specific situation of the school [3].It is emphasized that the system of teachers' behavioral teaching plans should be standardized and stereotyped in practice. In practice, it is emphasized that the system of teachers' behavioral teaching plans should be standardized and stereotyped.

\section{Countermeasures and suggestions}

\subsection{Broaden the channels of talent introduction}

Under the condition of inbreeding, the new teachers have a large part of the organizational culture, and they have great similarities in the world outlook, values and outlook on life. Although it is conducive to the organization of cultural heritage, the "inbreeding" teachers lack of communication with the external academic community [4]. "Inbreeding" teachers follow a similar research paradigm; it is difficult to create a new field of study, thus restricting the development of scientific research in Colleges and universities.Ithas become a routine practicethat many colleges and universities in the United States did not retain the school graduates at present.Some colleges and universities in the United States also made a provision for a higher degree. The final degree of a full-time teacher or senior management at Ohio University must be obtained outside the school. Our universities should establish the prevention mechanism, on the one hand to avoid inbreeding coefficient "of the school graduates in the new teachers selection, avoid learning edge structure simplification, to enrich the academic structure, so as to inject vitality into the scientific research and innovation. When choosing a new teacher, we must have a global vision, the international talent market. As vice president of City University Hong Kong professor Cheng Xing said, "the academic circles" is no longer in the country and the University as a unit, because talent first professional but not loyal to the University, the flow of talent not only in China but also in the 
international. He added that universities must compete in the region and globally. Local colleges restricted geographical, school conditions and other factors, the development degree is subordinate school low, the attraction of talent is not enough, so the college can be based on the domestic market from domestic research institutions, enterprises and society to introduce some solid foundation, experienced talents to university teachers, so it can't limited in the industry flow, play an active role in industry personnel involved in discipline construction, strengthen the relationship between University and society, to further promote the development of discipline. Local colleges and universities can focus on the construction of key disciplines to give play to the comparative advantages of key disciplines and gradually promote the import of international labor. Colleges and universities in the introduction of talent should not be confined to the domestic market and colleges and universities, but also to broaden the channels of introduction, from all walks of life to find the real talent into the ranks of teachers.

\subsection{Establish teacher training institutions to promote the development of Teachers}

The university should not only pay attention to check the quality of teachers in the early management process, but also in the follow-up management, intensify the cultivation of talents, constantly updating the teaching concept, improve teaching methods, help teachers improve teaching, scientific research and social service level. The burden of training should be given to the specialized agencies responsible for the implementation. We focused on the construction of a number of national teacher education development demonstration centers to promote the universal establishment of Teacher Education Development Center. There are plans to carry out the training of teachers for teaching and consulting to improve the young teachers' professional level and teaching ability. We should set up a special teacher training institutions in the local colleges and universities should be prepared as soon as possible to develop the teaching and learning center to fulfill the functions of teachers. The establishment of teacher education development center is to carry out a variety of training for teachers to improve teaching and research. We should focus on improving the quality of the training work after the establishment of the teachers' teaching development center, and strive to achieve the goal of "National Teacher Education Development Demonstration Center".

\subsection{Strengthen the humanized management}

Teacher culture is a sub culture of the school culture, which is the formation of teachers in teaching activities and values and behavior development mainly include teachers' occupation consciousness, role identity, education concept, value orientation, emotional and behavioral reactions [5][6].Local colleges and universities should gradually change the concept of management, with the "soft control" of teachers' culture to balance the "high voltage centralization" under the rigid institutional environment, so that the management of teachers is more humane. University education is characterized by individuality and creativity, respect for knowledge and respect for talent, only through the development of teachers' subjective initiative. The measure of success of school teachers' management depends largely on the degree of teachers' enthusiasm and creativity. Colleges and universities should be included in the school affairs, the system of the development process, to listen to their views. Too much administrative intervention and serious institutional constraints, can only suppress their subjective initiative; weaken their enthusiasm to participate in school management, deprived of their words and suggestions. Local colleges and universities should strengthen the infiltration of teacher culture, pay attention to play a positive leading role; mainstream, elegant and rational educational culture in the management of 
teachers in the system will standardize the external into Teachers' self-improvement, self-development capacity[7].

Our teacher management work still exists many problems, it is difficult to completely correct in the short term at present. First of all, we should keep a positive attitude. When faced with old problems, repeated problems, we can't let go regardless of the old management of the past. Second, we should also do a good job of "protracted war", the new management will be carried out until the existing problems disappear will not reproduce. We should attach great importance to the quality of teachers' management in order to promote the quality and development of higher education in a word.

\section{Reference}

[1]Zhou X. A Comparison Between Chinese and American Administration of College Teachers[J]. 2002.

[2]Sui $\mathrm{X} \mathrm{H}$. Comparison of the setup of college physical education administration between China and the United States[J]. Journal of Physical Education, 2007.

[3]Lucia F, Mihaela P L, Mihai I. Globalization Era And Human Resources Management[J]. RevistaEconomica, 2012, supplement:112-116.

[4]Hong L U, Ling $W$ Q. Application of EAP in the University Human Resources Management[J]. China Market, 2009.

[5]Liu X W. A Study on the Strategy of High-level Talent Introduction in Local Colleges and Universities in Shaanxi[J]. Journal of Baoji University of Arts \& Sciences, 2016.

[6]Guasch T, Alvarez I, Espasa A. University teacher competencies in a virtual teaching/learning environment: Analysis of a teacher training experience[J]. Teaching \& Teacher Education, 2010, 26(2):199-206.

[7]Dong L L. Research on the Problems and Countermeasures of Talent Introduction in Local Colleges and Universities[J]. Yinshan Academic Journal, 2006. 